\title{
Providing a forensic psychiatric service to Cardiff Prison
}

\author{
Phil Huckle and Tegwyn Williams
}

\begin{abstract}
The extrication of seriousty mentally disordered offenders from all stages in the criminal justice system from arrest to imprisonment is a major role for both general and forensic psychiatry. A survey of inmates In Cardiff Prison referred to an 'out-patient' forensic psychiatric service held weekly is presented. An alarming number of referrals were patients with schizophrenia.
\end{abstract}

In the 16th century Justices could order the detention of people deemed to be insane in houses of correction (Allderidge, 1990). The therapeutic team for these people consisted of the keeper of the house of correction and his assistants.

In 1993, many people with serious mental illness find themselves in a similar position in the modern houses of correction, the prison system.

The report of the Reed Committee (Department of Health and The Home Office, 1992) stated that the needs of seriously mentally ill prisoners cannot be met in prison.

The Report of the All-Wales Advisory Group on Forensic Psychiatry (Welsh Office, 1992) recommended close liaison between the developing forensic psychiatric service in Wales and prisons serving Welsh prisoners as part of its recommendations in setting up a comprehensive service.

In view of these recommendations a liaison forensic psychiatric service was developed between the South Wales Forensic Psychiatric Service and Her Majesty's Prison, Cardiff.

This paper looks at the referrals to this service in its first eight months.

\section{HMP Cardiff}

Cardiff Prison is based in the centre of the city and has places for 450 inmates. In a survey of the inmates on a day in October 1993 there were 329 adult inmates (aged over 21 years) and 96 young offenders. The prison is essentially a remand prison serving South-East Wales and has full-time medical cover with a senior medical officer, a medical officer and two local GPs doing sessions.

\section{The forensic liaison service}

In June 1992, a liaison forensic psychiatric service was set up whereby a consultant forensic psychiatrist and a senior registrar hold weekly 'out-patient' clinics within the hospital wing of the prison. Inmates are referred mainly by the prison medical staff. In addition to the weekly session, the South Wales Forensic Psychiatric Service provide an emergency assessment service so that inmates can be assessed urgently within 24 hours.

It has been estimated that 70 new inmates are received by the prison each week. Upon sentence, the majority are transferred through the dispersal system to prisons, usually in England.

\section{The study}

Data were collected from the clinical assessment records of the inmates who were referred as well as from their inmate medical files. For the purposes of this study, referrals of inmates from solicitors, the Crown Prosecution Service and other agencies within the Criminal Justice system were excluded from the analysis.

The inmates were referred because the prison staff identified possible signs of mental illness or there was a previous psychiatric history. Advice was sought regarding their management within the prison or for assessment regarding transfer out of the prison for urgent psychiatric treatment.

Inmates referred between June 1992 and February 1993 were studied regarding their demographic and clinical details.

\section{Findings}

During the period of study there were 60 inmates referred. Of these, $81 \%$ were remanded prisoners. The ages of the referred inmates were 15 to 45 years (mean 28 years). Twenty-three per cent were young offenders. The alleged or index offences in order of frequency were: acquisitive, i.e. theft, burglary, (48\%); offences against the person (33\%); arson (5\%); and drug-related offences (1.6\%). 
Table 1. Psychiatric diagnoses of the in-mates referred to the forensic service

\begin{tabular}{ll}
\hline DSM-III-R diagnosis & Number \\
\hline Schizophrenia & 16 \\
Drug addiction & 14 \\
Adjustment reaction & 9 \\
Dysthymia & 3 \\
Major depression with psychotic features & 1 \\
Bipolar affective disorder - manic & 1 \\
Drug-induced psychosis & 3 \\
Alcohol dependence syndrome & 4 \\
Mild mental handicap & 1 \\
Post traumatic stress disorder & 1 \\
Personality disorder & 2 \\
None & 3 \\
\hline
\end{tabular}

Forty-five per cent of the referrals had received in- or out-patient psychiatric treatment previously, often in the recent past, and $15 \%$ had been admitted compulsorily to hospital for psychiatric treatment under parts IV or V of the Mental Health Act, 1983 within the previous three years.

The reasons for referral to the forensic psychiatric service were to assess the inmates' mental state and advise on their management (61\%); to assess suicide risk (13\%); and to prepare a report to court on behalf of the prison (21\%).

Eighteen per cent of the referrals were Rule $\mathbf{4 3}$ or segregated prisoners. The psychiatric diagnoses of the referrals using DSM-III-R criteria (American Psychiatric Association, 1987) are shown in Table 1. Table 2 shows the interventions used following assessment of the referrals.
Table 2. Interventions used in the management of the inmates referred

\begin{tabular}{lr}
\hline Intervention & Numbers \\
\hline Counselling within prison & 5 \\
Psychotropic drugs recommended & 22 \\
Detoxification programme & 2 \\
S47 transfers to hospltals & 5 \\
S48 transfers to hospltal & 3 \\
S38 (Interim Hospital Order) & 4 \\
None & 3 \\
Probation with condition of Rx & 3 \\
S37 (Hospltal Orders) & 3 \\
Reports to court & 10 \\
\hline
\end{tabular}

Sections 47 and 48 of the Mental Health Act of 1983 are urgent transfers to psychiatric hospital for treatment of convicted and remanded prisoners respectively.

Sixteen prisoners were identified who met DSM-III-R criteria for schizophrenia. Five were convicted prisoners and 11 remanded prisoners. Table 3 shows the method of diverting these patients rather than prisoners out of prison and their index offences.

Of the sixteen patients, eight had been lost to follow-up from general psychiatric services, five were of no fixed abode, four were new cases and four had been given other diagnostic labels besides schizophrenia by previous psychiatrists, usually as a way of blocking transfer to hospital for treatment. The majority of these patients were transferred to general psychiatric services.

Table 3. Inmates with schizophrenia in Cardiff Prison

\begin{tabular}{|c|c|c|c|c|}
\hline Patient & Ago & Remanded/sentenced & Offence & Disposal \\
\hline 1 & 22 & $s$ & Affray & S47 \\
\hline 2 & 25 & $\mathbf{R}$ & Threats to kill & Probation \\
\hline 3 & 40 & $\mathbf{R}$ & Grievous bodily harm & $537 / 41$ \\
\hline 4 & 40 & $\mathbf{R}$ & Sex offence & S38 \\
\hline 5 & 40 & S & Robbery & $547 / 49$ \\
\hline 6 & 24 & $\mathbf{R}$ & Theft & Probation \\
\hline 7 & 30 & $\mathbf{R}$ & Assault & S38 \\
\hline 8 & 24 & $\mathbf{R}$ & Assault & s37 \\
\hline 9 & 29 & s & Non-payment of fines & Informal admission \\
\hline 10 & 25 & $\mathbf{R}$ & Sex Offence & SW48/49 \\
\hline 11 & 27 & $\mathbf{R}$ & Assault & S38 \\
\hline 12 & 27 & $\mathbf{R}$ & Criminal damage & S48 \\
\hline 13 & 19 & $\mathbf{R}$ & Attempt robbery & S48 \\
\hline 14 & 27 & $\mathbf{R}$ & Assault & S48 \\
\hline 15 & 21 & s & Robbery & S47 \\
\hline 16 & 22 & $S$ & Theft & S47 \\
\hline
\end{tabular}




\section{Comment}

The needs of severely mentally ill offenders cannot be met in the hospital wings of prisons. Gunn et al (1991) surveyed 5\% of prisoners in England and Wales and from their data suggested that 37\% had psychiatric disorders. They also estimated that there could be as many as 700 sentenced prisoners who are psychotic.

Hospital wings of prisons are not recognised as hospitals; therefore powers under the Mental Health Act of forcibly treating psychotic prisoners under this legislation is clearly inappropriate. Many psychotic prisoners therefore find themselves confined in 'strip' cells.

Remand prisoners are under particular stress and the mentally ill are over-represented among prison suicides. Taylor \& Gunn (1984) found that at least $9 \%$ of men remanded to Brixton prison were psychotic.

We were particularly concerned about the number of prisoners suffering from schizophrenia within Cardiff Prison. It has been estimated in a ten year follow-up of patients with schizophrenia in the community that $30 \%$ had some contact with the police and $12 \%$ were convicted of offences which were usually minor. Many of the offences took place because the patients were unable to care for themselves or had behaved inapproprtately in a public place (Johnstone, 1991).

General psychiatrists need to be actively involved in the diversion of the mentally ill from the criminal justice system at all levels, from arrest by police to the extrication of the seriously mentally ill convicted prisoner. General psychiatrists ask where the extra resources are to come from to look after the diverted offender patients. The answer is that the majority of the schizophrenic inmates in our series were already known to general psychiatric services. Mentally disordered offenders should not be denied treatment merely by being offenders.

\section{Acknowledgements}

The authors would like to thank the Governor and staff of Cardiff Prison for their help in setting up this service.

\section{References}

ALLDERIDGE, P. (1990) Hospitals, madhouses and asylums: cycles in the care for the insane. In Lectures on the History of Psychlatry (Eds. Murray, R.M. \& Turner, T.H.). London: Gaskell. (Royal College of Psychiatrists).

AMERICAN PSYCHIATRIC ASSOCLATION (1987) Diagnostic and Statistical Manual of Mental Disorders (3rd edition. revised) (DSM-III-R) Washington, DC: APA.

DepartMent OF HEALTH \& HOME OFFICE (1992) Review of Health and Social Services for Mentally Disondered Offenders and Others Requiring Similar Services: final summary report (Reed Committee) (CM 2088) London: HMSO.

GUNN, J., MADEN, A. \& SwINTON, M. (1991) Treatment needs of prisoners with psychiatric disorders. British Medical Journal, s03, 338-341.

JOHNSTONE, E.C. (1991) Disabilities and circumstances of schizophrenic patients: a follow-up study. British Journal of Psychiatry. 160, Suppl 1. 13.

TAYOR, P.J. \& GUNN, J. (1984) Violence and psychosis - risk of violence among psychotic men. British Medical Journal 288, 194-198.

WELSH OFFICE (1992) Report of the All-Wales Advisory Group on Forensic Psychiatry. Cardiff: HMSO.

P.L. Huckle, Senior Registrar in Forensic Psychiatry; and Tegwyn Williams, Consultant Forensic Psychiatrist, The South Wales Forensic Psychiatric Service, The Caswell Clinic, Glanthyd Hospital, Bridgend, Mid Glamorgan CF31 4LN

\section{Addendum}

Since the submission of this article, Cardiff Prison have changed their policy regarding the use of the unfurnished cell (the 'strip' cell). It is used only to manage actively suicidal prisoners, not to contain those who are psychotic. 